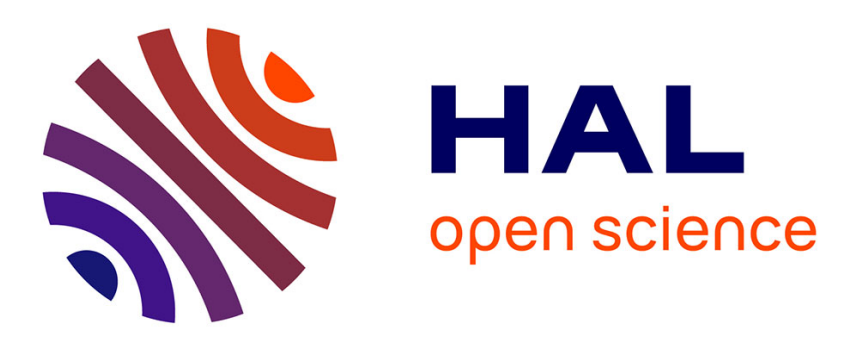

\title{
How can Country-of-Origin image be leveraged to create global sporting goods brands?
}

Anna Gerke, Nicolas Chanavat, Maureen Benson-Rea

\section{To cite this version:}

Anna Gerke, Nicolas Chanavat, Maureen Benson-Rea. How can Country-of-Origin image be leveraged to create global sporting goods brands?. Sport Management Review, 2014, 17 (2), pp.174-189. 10.1016/j.smr.2013.06.001 . hal-01081136

HAL Id: hal-01081136

https://hal-audencia.archives-ouvertes.fr/hal-01081136

Submitted on 21 Nov 2014

HAL is a multi-disciplinary open access archive for the deposit and dissemination of scientific research documents, whether they are published or not. The documents may come from teaching and research institutions in France or abroad, or from public or private research centers.
L'archive ouverte pluridisciplinaire HAL, est destinée au dépôt et à la diffusion de documents scientifiques de niveau recherche, publiés ou non, émanant des établissements d'enseignement et de recherche français ou étrangers, des laboratoires publics ou privés. 


\title{
How can Country-of-Origin image be leveraged to create global
}

\section{sporting goods brands?}

\author{
Anna Gerke ${ }^{\mathrm{a}{ }^{*}}$, Nicolas Chanavat ${ }^{\mathrm{a}}$, Maureen Benson-Rea ${ }^{\mathrm{b}}$
}

a. University of Paris South, Faculty of Sciences and Techniques of Physical and Sporting Activities, Department of Sport Marketing and Management, 91405 Orsay cedex, France

b. University of Auckland Business School, Department of Management and International Business, Owen G Glenn Building, 12 Grafton Road, Auckland, New Zealand

${ }^{1}$ Part of this research was carried out by the first author while at the third author's institution.

* Corresponding author: Anna Gerke, anna.gerke@u-psud.fr, phone: +33(0)2.40.37.81.37

\begin{abstract}
While much marketing research has focused on brand creation and management, less is known about the creation of sport brands. This paper complements the stakeholder model of branding and brand creation, which highlights the role of a firm's stakeholders in the analysis of brands, by including country-specific factors based on location and Country-of-Origin (CoO). Using a sample of innovative New Zealand-based firms, our qualitative study uses a comparative case method in two subsector settings to investigate how they have built outdoor sport brands based on that country's particular country-specific factors. We show how firms are able to leverage New Zealand's strong sport product category-country associations to create brand value. Our findings confirm that $\mathrm{CoO}$ image together with sport product category-country associations enables the creation of brands in sport product categories. Our paper contributes to theory and practice by extending understanding of brand creation by demonstrating the importance of location and product category. Further research directions are suggested.
\end{abstract}

\section{Keywords}

Brand creation, Country-of-Origin $(\mathrm{CoO})$, Sport product, Outdoor sport 


\section{Introduction}

There is a strong trend towards the globalisation of the sport economy (Andreff, 2008). This trend concerns not only sport events, sport sponsorship, and sport media, but also and especially sporting goods firms. Fullerton and Merz (2008) differentiate sport products categories and define the tangible sport product category as the total range of sporting goods, apparel, athletic shoes, and other sports-related products. Andreff (2009) observes an increasing globalisation of supply and demand for sporting goods alongside a trend to more global trading of sporting goods. Firms tend to have globalised value chains, international markets, and competitors from all over the world. Brand management has gained importance in both sport consumer goods and specialised sporting equipment as brands serve to differentiate a firm from another. The need for differentiation increases with the advancement of globalisation and competition.

A brand is defined as: "Name, term, design, symbol, or any other feature that identifies one seller's good or service as distinct from those of other sellers." (American Marketing Association, 2012). The notion of a brand can be differentiated in the two concepts of brand value and brand equity (Jones, 2005). In Jones' (2005) definition brand value is perceived as how the value of a brand is created, while equity refers to how a brand and its value are measured and accumulated. Keller and Lehmann (2006, p. 751) argue that "Brands are made, not born", which is supported by Jones in a stakeholder model of brand equity and value, which states that brand value is created in interaction with multiple stakeholders which adds up to brand equity. Vargo and Lusch (2004) emphasise that marketing is mostly concerned with the co-creation of value, and in the context of brand value creation, Jones' (2005) stakeholder model constitutes an approach that helps brand managers to answer the two fundamental questions in brand management: (1) where does the brand value lie? And, (2) how is this value (co) created? Jones' (2005) stakeholder model of brand value creation shows that brand value is not simply created by the customers but also includes other relevant stakeholders (e.g., suppliers, distributors, competitors or media) . This 
article offers a complementary approach to extant models of brand value creation through the inclusion of the firm's home country and its country-specific characteristics.

Previous research proposes that country-of-origin $(\mathrm{CoO})$ reputation can positively impact on the creation of strong brands (Fournier, 1998; Lefkoff-Hagius \& Mason, 1993; Pappu, Quester, \& Cooksey, 2005). This can be both in terms of a nation's brand and in terms of national firms' brands. Hence, we argue that a strong $\mathrm{CoO}$ reputation facilitates the creation of brands. The conditions for this mechanism are an alignment of the values transmitted by the $\mathrm{CoO}$ image and the brand values. In past $\mathrm{CoO}$ research this has been referred to as "product-country-match" (Roth \& Romeo, 1992). Another sub stream of CoO research has emerged, namely "product-country-image", which summarises the connotations and stereotypes that are generally associated with a country and its people, products, culture, and national symbols (Askegaard \& Ger, 1998; Papadopoulos, 2004; Verlegh \& Steenkamp, 1999).

In this paper we argue that $\mathrm{CoO}$ image can also be a source of brand value if there is a countryproduct match, i.e. if the country characteristics remind the consumer of certain products or a product category (Pappu, et al., 2005). Brand value based on the firm's origin, the country, can be created if the consumer associates the country's image positively with the product or product category for which the brand will be created. We analyse this proposition in the context of the strategies pursued by sport equipment firms based in New Zealand. This study extends the current stakeholder model of brand value creation by considering the origin of the firm and how firms use it to develop strong brands.

The paper is structured as follows. First, we set out the links between the two key concepts of branding and the $\mathrm{CoO}$ effect. Based on this review we derive propositions to put forward our theorised relationship between $\mathrm{CoO}$ effect and brand creation. In the third section we set out the methods that were employed, including the research design, data collection, and data analysis. Finally we present our findings and conclude with a discussion of our findings reflecting back on our initial propositions. 


\section{Theoretical Framework}

In order to set out our theoretical framework and the resulting propositions, we review key literature on branding and $\mathrm{CoO}$ effects, and their contextualisation in research on sport management and marketing. Furthermore we discuss previous studies that relate the concepts $\mathrm{CoO}$ and brand creation to each other. Based on this literature review we derive propositions that we later test using empirical data gathered in two sporting goods sectors which compete on the basis of brands.

\subsection{Brand concept(s)}

The practice of branding has been deployed for centuries as a means for producers to distinguish their goods against those of competitors by creating a recognisable and memorable image. Since the early 1950s, brands have constituted an important concept in consumer behaviour and marketing research for scholars and practitioners. Brands are ubiquitous in the everyday life of consumers and a brand is widely considered to be the most important asset of a company (Keller, 1993). A review of the marketing literature reveals a number of conceptual refinements to define the consumer's perceptions linked to a brand, such as brand knowledge, brand equity, brand image, brand association or brand awareness (Chanavat, Martinent \& Ferrand, 2009).

Customer knowledge about brands creates the main source for customer-based brand equity and is composed of brand awareness which relates to consumers' ability to recognise and recall the brand (i.e., whether, and when, consumers know the brand), and brand image which consists of consumers' associations and perceptions for the brand (i.e., what are the semantic associations that consumers have with the brand) (Keller, 2003). Brand awareness "is related to the strength of the brand node or trace in memory, as reflected by consumers' ability to identify the brand under different conditions [...] in particular brand name awareness relates to the likelihood that a brand name will come to mind and the ease with which it does so" (Keller, 1993, p. 3). Brand awareness can be measured through brand recall or brand recognition. Brand recall “relates to consumer's ability to retrieve the brand when given the product category, the needs fulfilled by the category, or some other type of probe as a cue" (Keller, 1993, 
p. 3), while brand recognition "relates to consumers' ability to confirm prior exposure to the brand when given the brand as a cue” (Keller, 1993, p. 3). Second, Keller (1993) advanced the idea that brand image is defined by the sorts of brand associations that consumers hold in their memories, which are in turn defined by each brand's attributes and benefits, and the customer's attitude towards those. Attributes represent product-related elements, which are those necessary for the product or service to perform, and non-product related elements, which are external aspects of the product or service that relate to its purchase or consumption. Benefits are related to the personal value which consumers assign to the product or service and consist of functional, experiential, and symbolic dimensions. Functional benefits are related to the product's or service's intrinsic advantages, experiential benefits relate to what it feels like to use the product or service, and symbolic benefits represent the extrinsic advantages of the product or service's consumption. Brand attitudes are consumers' overall evaluations of a brand and brand associations may be considered to be like information nodes linked to a brand node in consumers' memories, containing what the brand's meaning is for people. Brand associations include multiple types of perceptions held in consumers' memories, even those from the distant past (Keller, 1993). In other words, brand image can be defined as consumer perceptions of and preferences for a brand, as reflected by the various types of associations held in memory. This approach builds on earlier conceptualisations, which regarded brand associations, perceived quality, brand loyalty, and competitive advantage as the components of a brand (Aaker, 1996).

The stakeholder model of brand value creation (Jones, 2005) is closely related to the intricately linked concepts of brand value and brand equity. Brand value is the net present value of future cash flows from a branded product minus the net present value of future cash flows from a similar unbranded product or, in simpler terms, what the brand is worth to management and shareholders (Tiwari, 2013). In this perspective, brand value considers the role of relationships in value creation and brand equity considers the assessment of the value that is created through these relationships (Tiwari, 2013). In relation to brand equity, the stakeholder concept (Jones, 2005) gives us a much richer picture of sources of brand value and equity. It requires the analysis of the range of relationships that the brand is engaged in and the recognition 
that brand equity is created through multiple relationships. The stakeholder approach represents an important tool for managing these relationships but also a tool to provide an overview and prioritise those relationships that are strategically important (Freeman, 1994). Jones' (2005) stakeholder model of brand value was developed to strengthen understanding of the sources of brand value. It attempts to provide an overarching model for creating and assessing brand value and to link the different streams within the literature. Five important points arise from Jones's (2005) model. First, brand value depends on stakeholders and these function as a network supporting (or working against) brand value. It is important to achieve synergy between these different relationships, building the value of positive interactions and minimising the influence of negative associations, in order to reach high brand value. Second, stakeholders, other than customers, can represent crucial sources of brand value. Third, brand value does not equal the total of the value of each stakeholder relationship. In brand equity terms each individual association is considered independently and the whole is greater than the sum of its parts. Fourth, each association has its own logic, which determines the nature of the interaction and how outcome performance should be gauged. The brand manager needs to identify the variables that are most effective (e.g. financial return on investment or environmental issue). Last, brand value is co-created through the relationships between the brand and its stakeholders (Jones, 2005). Consequently, the brand manager needs to select which relationships are most relevant for the success of the brand (Keller, 2003.

Brands and branding represent strategic leverage to create value for organisations in general (Lewi, 2005) and this is particularly salient in the sport sector. Previous research has underlined the importance of branding in sport (Bauer, Sauer, \& Schmitt, 2005; Chanavat \& Bodet, 2009; Ferrand \& Pagès, 1999; Mullin, Hardy, \& Sutton, 2007; Pons \& Richelieu, 2011) but, despite keen interest regarding branding in sport, almost all research has focused on brand image in the contexts of sporting events, professional sports, sport sponsorship, or sport media (Bodet \& Chanavat, 2010; Chanavat, Martinent, \& Ferrand, 2009; Ferrand \& Pagès, 1999; Gladden \& Funk, 2002; Richelieu \& Desbordes, 2009). By examining the brand creation for one-off international sporting events, Parent and Seguin (2008) and Parent, Eskerud and Hanstad (2012) represent exceptions regarding research on brand builders in sport. Parent et al.'s study 
(2012), based on Parent and Séguin's (2008) model for one-off sports events, compared case studies of the Alberta World Cup (Canada) and the World Cup Drammen (Norway) cross-country ski events. They found resemblances between them, highlighting the importance of leaders' skills/value-based actions, induced event experiences, and institutional experiences. Some dissimilarities were also observed around branding/marketing efforts, recognition of the sport, and the nature of the event (success, media coverage, geographic location, and history/impact). They proposed an expanded model of event brand creation, which, they argue, can be applied to both one-off and recurring sporting events in small or large North American or European cities. We have identified very few studies, however, which focus on sporting goods firms and their brands, though some have been done on manufacturer's brands. For instance, Kwon, Kim and Mondello (2008) studied whether manufacturers' brands influenced sport consumers' reactions towards and purchase intentions of licensed apparel. Three different brands were assessed: Nike, Starter, and Specs (though 'Specs' represented a generic brand proposed by the scholars to symbolise an unknown brand). The results of that research showed that sport consumers' attitudes were determined by their attitude regarding a manufacturer. Furthermore, it was demonstrated that consumer attitudes were modified by their team identification. The influence of a manufacturer's brand decreased among individuals reporting high team identification, which could be partially explained by classical conditioning (Kwon, et al., 2008).

Powerful brands create meaningful images in the minds of consumers (Keller, 1993), with brand image and reputation developing differentiation and thus potentially having a positive impact on consumer conative reaction (McEnally \& De Chernatony, 1999). Moreover, branding in consumer markets has been shown to increase a firm's financial performance and long-term competitive position (Mudambi, 2002). It can be noted, however, that there is very little research on sporting goods branding and our review reveals that this is a potentially fruitful area. Today's global sports industry is worth between $€ 350$ billion and $€ 450$ billion (US\$480-\$620 billion), according to a recent study by AT Kearney (2011) of sports, which included infrastructure construction, sporting goods, licensed products and live sports events. The economic and financial contributions of the industry underline its research importance. 


\subsection{Country of Origin (CoO) effect}

The $\mathrm{CoO}$ effect describes the notion that the $\mathrm{CoO}$ is an informational cue extrinsic to the product which affects evaluation of the product, its attributes, and the consumer's overall perception of the product (Pappu, et al., 2005; Thakor \& Katsanis, 1997; Verlegh \& Steenkamp, 1999). The term CoO can be defined as the country in which a product is made (Thakor \& Katsanis, 1997), though this definition provokes criticism as, with increasing internationalisation of firms and globalisation of industries, the value creation process from the idea for a product, to its design, manufacture, and marketing often crosses several borders. Thakor and Kohli (1996, p. 27) use the narrower notion of brand origin which they define as "the place, region or country to which the brand is perceived to belong by its target consumers". An additional indicator of the $\mathrm{CoO}$ can be the headquarters' country of the firm which owns the brand. This is the relevant defining characteristic in our study.

Dichter (1962) was the first to theorise the existence of a CoO effect in his study on the role of nationalism in customer behaviour. The first empirical research on $\mathrm{CoO}$ was conducted by Schooler (1965) which showed that attitudes towards people from a certain country influence the perception of products made in that country. Dinnie (2004a) and Verlegh and Steenkamp (1999) provide extensive reviews of the CoO literature. Dinnie (2004a) takes a temporal approach and argues that there are three main periods in the chronological development of CoO research. The first period, 1965-1982, is characterised by fundamental research towards the conceptualisation of the $\mathrm{CoO}$ using single cue studies. A major advancement of the concept was the research conducted by Bilkey and Nes (1982) who found that CoO affects product evaluations and consequently emphasised the importance of the $\mathrm{CoO}$ concept for exporting countries and firms that source and sell internationally. The second period of CoO research as defined by Dinnie (2004a), 1983-1992, was something of a setback for the CoO concept because multi-cue studies, that took into consideration other factors such as price and quality, suggested that $\mathrm{CoO}$ effects are much less important for product evaluations than previous studies had indicated (Johansson, Douglas, \& Nonaka, 1985). During the third period of $\mathrm{CoO}$ research, 1993-2004, many related streams have emerged from the original $\mathrm{CoO}$ 
notion, including $\mathrm{CoO}$ in terms of brand origin (Thakor \& Kohli, 1996), product-country images (Askegaard \& Ger, 1998; Papadopoulos, 2004), and product category-country associations (Dinnie, 2004a; Pappu, et al., 2005).

Research on product-country images examines the link between the image of a country and the image of products or services made in that country (Dinnie, 2004a). Its objective is to find to what extent the place or country where a product or service is created influences consumer behaviour and purchase decisions. This concept assumes that consumers transfer associations related to a country to products and services that are created in that particular country. Place images are used to market the products associated with those places, usually when marketing managers believe that the image of the product's origin is strong and its positive associations will serve to sell the products. Usually the product's origin is used in marketing communication and branding. It has been argued that product-country image is especially important for the tourism and agriculture sectors, although it has also been employed as a marketing method by individual producers of manufactured goods, mostly to promote exports (Papadopoulos, 2004).

Product category-country associations refer to the ability of consumers to link a country with a product category. Similarly to product category-brand associations, the consumer is able to evoke the country when the product category is mentioned. This works also in the opposite direction, meaning that consumers remember the product category when they country is mentioned. Hence, it is a bi-directional phenomenon (Pappu, et al., 2005). Product category-country associations are interesting factors for managerial decisions in terms of location and marketing strategies (Dinnie, 2004a). If there is a high product category-country match, information associated with a $\mathrm{CoO}$ image is not only transferred to a product or brand but to an entire product category. For example German car brands have attained a high international reputation for high technical quality. This positive association has been transferred to the German car industry in general (Verlegh \& Steenkamp, 1999). Another example is wine from New Zealand, which was able to build on the country's reputation for quality agricultural products to create a premium national wine brand (Brodie, Benson-Rea, \& Lewis, 2008) which has been used to develop company brands in that product category, and indeed has been mimicked by a French producer selling "Kiwi Cuvée" (Iverson, 2010; NZ 
Herald, 2010). The place image (CoO) can be used to tell a story about the product's origin, and hence can be used to create brand value, a process which consists of the transfer of positive associations of the product category with the $\mathrm{CoO}$ to positive associations of the brand with the $\mathrm{CoO}$ (Askegaard \& Ger, 1998). Hence, product category-country image can be used to create product category specific brands building on $\mathrm{CoO}$ effects.

$\mathrm{CoO}$ related research has also been emerging in combination with research in sport management. The research focus has been on the role of location and image of host cities and countries for sport events (Brown, 2000; Emery, 2010) on one hand, and on sport tourism destinations on the other (Hinch \& Higham, 2001; White, 2012). Furthermore country-specific factors have been studied in relation to consumption of sport products and services considering cultural and social differences (Allen, Drane, Byon, \& Mohn, 2010; Thomas \& Dyall, 1999). However, we have found only one study that refers explicitly to CoO image and effect (White, 2012), though Dinnie (2004b, p. 108) emphasises that: "The significance of sport as determinant of country image perceptions has been massively underestimated in existing country-of-origin research". He argues that sport events, national sport media coverage, and national sporting achievements can play an important role in creating a nation's brand. An important role is played here by national athletes and teams and their presence at sport events in the home country, with such examples as New Zealand's rugby team the All Blacks and the Rugby World Cup in 2011, Germany's national soccer team at the FIFA World Cup in 2006, the Serbian tennis player Novak Djokovic since 2008, the sailing team Groupama in the Volvo Ocean Race 2012, and its stopover at the team's home base in Brittany, France. Moreover, the globalisation of some sport brands may lead to their taking on a life of their own, beyond an association with their country of origin, for example, Nike (USA) and Adidas (Germany).

\subsection{CoO and brand creation - research propositions}

A limited number of $\mathrm{CoO}$ and brand-related issues have been studied, from different theoretical perspectives (Kotler \& Gertner, 2002; Papadopoulos, 2004; Pappu, et al., 2005; Thakor \& Kohli, 1996). In 
this section we argue for the need for further investigation of how $\mathrm{CoO}$ can facilitate the creation of brands, especially in the sporting goods industry.

Kotler and Gertner (2002, p. 251) argue that: “A country's image results from its geography, history, proclamations, art and music, famous citizens and other features.", and suggest that each country should conduct a SWOT ${ }^{1}$ analysis and then choose some industries and country features such as personalities, natural landmarks, and historical events that promote the $\mathrm{CoO}$ image in the selected industries. Askegaard and Ger (1998) argue that $\mathrm{CoO}$ is consciously consulted by consumers in order to gather information about a country, its people, and products, indeed brands are increasingly a vehicle for consumers to learn about national identities (Anholt, 2002). Reversing this argument would mean that country-specific information can create a CoO image. Building on Dinnie (2004b), sport in the form of sport events, media coverage, and national sporting achievements can significantly influence national brand creation. Based on these assumptions we propose the following proposition:

Proposition 1: Sport is a country-specific factor that influences CoO image.

Pappu, Quester and Cooksey (2005) investigated the impact of $\mathrm{CoO}$ on brand equity and found that the match of product category and country image perceptions influences brand equity. The brand equity of a brand made in a country with strong product category-country associations is higher than for the same brand in a country with weaker product category-country associations (Pappu, et al., 2005). Based on these insights we argue that brand value can also be actively created based on $\mathrm{CoO}$ if there is a high product category-country match. Thus:

Proposition 2: A CoO with strong sport product category-country associations enables the creation of brands in those categories.

\footnotetext{
${ }^{1}$ SWOT is the acronym for: Strengths, Weaknesses, Opportunities, Threats.
} 
Our third proposition concerns our research context, the outdoor sport goods industry. We explore the role of sport within a $\mathrm{CoO}$ image for brand creation in the outdoor sport goods industry. We argue further that sport and country-specific traits related to sport facilitate the creation of national sport product category brands and the related brand value. In our study we test this using data on the outdoor sport image of New Zealand and respective outdoor sport equipment brands.

Proposition 3: Firms from countries with a strong outdoor sport related CoO image actively use it to create global outdoor sport brands.

We believe that our research propositions are interesting and original. They are interesting because limited previous research highlights the importance of $\mathrm{CoO}$ research in relation to sport (Dinnie, 2004a, 2004b). As it was previously discussed in the overview previous research has focussed on the impact of $\mathrm{CoO}$ on sport events, professional sport entities, and sport tourism and vice versa, but not on the impact of $\mathrm{CoO}$ on sport product brands originating from that country.

\section{Method}

We examine extant theory in a new context, and to extend that theory by deploying a qualitative and deductive research strategy (Bohm, 1977), complemented by an inductive analysis. A comparative case study using two case settings was undertaken in order to investigate the role of $\mathrm{CoO}$ in the creation of brand value from the firms' managers' perspective. The unit of analysis is the case setting, i.e. the subsector. Primary data sources are ten semi-structured interviews with managers from firms in the subsectors which were supplemented by secondary data such as advertising material, research reports, company case studies, online articles, etc. 


\subsection{Case study setting}

The outdoor sport goods industry was chosen as the empirical context. Two subsectors of this industry were selected as case settings, the outdoor clothing sector and the yachting sector. The cases were selected for theoretical reasons as they are thought to explain the investigated phenomena best and are most likely to extend the theory (Eisenhardt, 1989). In each subsector five firms were selected that seemed to present the subsector best. A heterogeneous group of firms was chosen in terms of size, core product, and age. Our sample selection was based on three criteria:

a) The firms are indigenous to New Zealand.

b) The firms use differentiation strategies.

c) The firms have a high level of export.

\subsubsection{Case Setting 1: Outdoor clothing sector}

Firms in the outdoor clothing sector include firms that have grown their core business around different specific sport disciplines or clothing material. Total household spending on sport clothing in New Zealand (NZ) in 2006/2007 amounted to NZ\$41.3mio. (approximately €19mio.) (Dalziel, 2011). Exports in this segment have little impact on total NZ exports (NZ\$3.2mio., approximately $€ 1.7 \mathrm{mio}$ ) because clothing is

usually produced outside of New Zealand, and hence not counted in exports. However, in a recent industry report on the economic and social value of sport and recreation to New Zealand, the importance of New Zealand outdoor fashion designers and brands is emphasised, referring partly to our case firms (Dalziel, 2011). Table 1 shows the profile of each firm within case setting 1 , the outdoor clothing sector. In the following we elaborate on the New Zealand outdoor clothing sector since a basic understanding of the sector and its properties helps to show later how this case supports our propositions.

<Insert Table 1> 
New Zealand benefits from a worldwide reputation as a great place for outdoor activities (SPARC, 2008). Furthermore New Zealand enjoys the image of being a "green and clean" country, producing products with the same attributes. This has created a "Brand New Zealand" which also finds application in the outdoor clothing sector. New Zealand's unique natural resources and rugged outdoor environment provide perfect conditions to develop and test new and innovative outdoor sport clothing, with superior performance when compared with other products from overseas (Textiles NZ, 2010). One of the factors enabling the development of superior outdoor apparel is the high level of outdoor sport activity in the country itself which creates stable local demand and the creativity for innovations. The diverse and often challenging outdoor environments such as mountains, volcanos, coastlines, remote forests, islands, lakes, rivers, etc. create challenging test conditions. This has led to a number of highly innovative firms producing high performance outdoor clothing (Heath, 2006; Unsworth, 2010), which provide perfect examples to investigate our propositions, i.e. the extent to which firms can and do use the $\mathrm{CoO} \mathrm{New}$ Zealand to create brand value which might boost international sales. The ingredients for world class outdoor sporting products are not only creative people and favourable environmental settings but also the right raw materials. One example of this is the merino sheep that provide a high quality fibre for the production of outdoor clothing as it combines unique properties (light, breathable, non-flammable, antiodour, biodegradable, quick-dry (Heath, 2006)) which have not been found in any other fabric in this combination. Even though similar fabric is produced elsewhere (e.g. Australia), New Zealand has managed to create a unique reputation for the superior quality of New Zealand-sourced merino wool, which contributes to the value of the product's $\mathrm{CoO}$.

\subsubsection{Case Setting 2: Yachting sector}

Firms in the yachting sector include boat-builders of different boat types, boat component builders, refitting and other marine services. According to a report by the Harvard Business School evaluating the New Zealand marine cluster, this industry represents NZ\$1.9bn in 2009 (approximately €850mio.) (Ireland, Satchcroft, Mayson, \& Janzarik, 2009). Table 2 shows the profile of each firm within case setting 
2, the yachting sector. In the following we elaborate on the New Zealand yachting sector since, again, a basic understanding of the sector and its development helps to show later how this case supports our propositions.

\section{<Insert Table 2>}

New Zealand has a long maritime history of sailing and boat building. The origins of the yachting industry lie in the pre-colonial needs of settlers and traders. Early Polynesian settlers as well as European migrants developed their settlements around coasts and rivers relying on water-based transport in the initial phase of their settlements. Together with an extensive timber supply, this led to an early development of a strong boat-building industry for internal demand but also export markets (Glass \& Hayward, 2001). The development of the boat-building sector has attracted further boat-related specialised firms that produce and deliver boat components or other boat-related products or services such as masts, design, sails, electronics, navigational equipment, etc. This has led to a concentration of boat-building related firms and sectors which denominate a geographical area around Auckland, referred to as a maritime cluster, including professional and leisure yachting (Chetty, 2004; Ireland, et al., 2009). New Zealand's natural endowment with huge and beautiful coastlines and islands fostered the diffusion of sailing as a leisure and sporting activity. Together with the successful boat-building industry this has stimulated the development of highly-skilled sailors and the creation of some of the fastest high performance ocean racing boats. Sporting events such as the America's Cup and the Volvo Ocean Race enabled not only the international exposure of New Zealand sailors and their boats, but also the presentation of Auckland and New Zealand as a centre of the sailing world and a centre of excellence for sailing products (Glass \& Hayward, 2001; New Zealand Marine Industry Association, 2012; NZTE, 2010). 


\subsection{Data collection}

Data were systematically collected from three sources as recommended for industry case study research (Chetty, 2004; Yin, 2009):

a) Ten semi-structured interviews with the $\mathrm{CEO}^{2}, \mathrm{GM}^{3}$ or equivalent decision-maker in the firm;

b) Ex ante and ex post requests via phone or email for clarification and review of the data, and

c) Archival data, including firm websites, business publications, firm brochures, published case studies, websites of trade organisations and shows, and other material provided by the informants or publicly available.

The main data source was the ten semi-structured interviews. The interview guide contained four sections. The first section was about the firm itself, its products, history, values, and visions. The second contained questions concerning the industry sector of the case firm. The third section posed questions about the internationalisation of the firms and what factors were important, such as for example "When and how did your company begin internationalising?". The final questions were about the role of the location New Zealand as a brand for the success of the firm, especially for sales outside the home market New Zealand. One of the questions was for example "To what extent is being a company from New Zealand important to your business and why?". The aim of the interview guide was firstly to elicit an introduction to the firm and the industry, then to provoke discussion around the notion of the $\mathrm{CoO}$ New Zealand as a brand without directly prompting it. We were curious to see whether the interviewees consciously considered and used the $\mathrm{CoO}$ New Zealand for brand value creation or other brand related issues or not. At the end of the interview, we asked directly what role the location New Zealand plays. The ten interviews were all conducted face-to-face with one exception (a video call). The interviews varied in duration between 30 and 80 minutes and each was recorded and transcribed verbatim by a professional transcriber. The information gathered was verified by ex ante and ex post telephone calls and emails in order to avoid interpretation errors during data analysis. Based on the verified interview transcripts case

\footnotetext{
${ }^{2} \mathrm{CEO}$ is the acronym for: Chief Executive Officer.

${ }^{3} \mathrm{GM}$ is the acronym for: General Manager.
} 
summaries were written which were checked and corrected if necessary by the interviewees. Archival data were used to complement the information gathered in the interviews.

\subsection{Deductive data analysis}

For the data analysis we follow the illustrative case of how to use NVivo as a research management tool by Bandara (2006). Bandara (2006) shows that NVivo is an effective software tool for three different research phases in management research: literature review, case study, and survey, though we only follow her guidelines concerning case study research. For the analysis of our data we created two NVivo databases, one for "Setting 1: Outdoor clothing sector" and one for "Setting 2: Yachting sector". All primary data as well as secondary data were imported into NVivo. The coding process was conducted in three stages:

\subsubsection{First coding round: A priori constructs, sub nodes, and emerging nodes}

A set of a priori nodes was created. These a priori nodes refer to constructs based on the propositions set out in Section 2.3 above. The data were examined and coded for factors indicating these $a$ priori constructs. When potential new constructs appeared either "sub nodes" or "emerging nodes" were created, and the data coded accordingly. Sub nodes are elements that deconstruct the a priori nodes. Emerging nodes combine key information relevant to the research question but they might apply to several propositions. When a new node was constructed material that had already been coded was examined a second time to check for relevance to the new construct. Four emerging nodes were identified for the outdoor clothing sector coding: brands, materials/resources, New Zealand, and sport. In the yachting sector we eliminated the emerging node materials/ resources as it proved not to be relevant for this industry sector.

\subsubsection{Second coding round: node system and re-analysis of coded data}

A coherent system of nodes and sub nodes reflecting the propositions was developed during the coding process. Proposition 1 contains the sub nodes "Sport" and "CoO Image". Proposition 2 contains 
the sub nodes "Category-country associations" and "Sport category brands". Proposition 3 contains the sub nodes "Outdoor CoO" and "Global outdoor brands". The data coded under each emerging node was re-analysed in order to make sure that they were relevant. Otherwise the coded information was discarded. Data retained under the emerging nodes was assigned to either one of the a priori nodes or to one of the sub nodes.

\subsubsection{Third coding round: significance of coded data}

The remaining a priori nodes and sub nodes and the coded information were analysed in terms of their relevance and frequency. By counting occurrences of terms we distinguished to what extent the coded data indicated the mere existence of sub constructs versus the explicit confirmation of constructs, and hence our propositions. This three-stage process was conducted for both case settings. Based on this analysis we concluded to what extent our propositions were confirmed and any limitations of our study.

\subsection{Inductive data analysis}

An inductive analysis was conducted across the first case setting to test Proposition 3 as it was only weakly supported in the deductive analysis in the outdoor clothing sector and barely in the yachting sector. We re-examined the primary and secondary data of the outdoor clothing sector cases without any predefined constructs in mind but the question of how outdoor sport equipment companies develop their brands. We used NVivo to conduct the analysis and identify relevant information and employed a narrative method to document the results of the inductive analysis (Yin, 2009).

\section{Results}

In this section we outline the results of the deductive analysis for each proposition and their sub constructs in the outdoor clothing sector first and then in the yachting sector. Secondly we outline the results of the inductive analysis. 


\subsection{Results for the deductive analysis}

\subsubsection{Results for the outdoor clothing sector}

\section{Proposition 1}

Table 3 shows the quantitative coding results for Proposition 1 and its sub constructs.

$<$ Insert Table 3>

Overall 39 references were coded referring to 18 sources (10 if we exclude double use of sources). One reference is defined as a continuous citation of text from one of our data sources. It can vary in size from a part of a sentence to a paragraph. One reference can also be a picture for example a logo or advertisement of a firm. The strongest coding was identified for the sub construct Sport (25 references), while for the sub construct $\mathrm{CoO}$ image little evidence could be found (6 references). For Proposition 1 , that combines the two sub constructs, little evidence was found ( 8 references). However, this was significant in qualitative terms as will be shown with interview extracts later on.

Table 4 shows the extent to which data in our cases related to our theorised propositions. The column "Sources" shows which cases provided relevant references and with what frequency. The column "References" shows how many citations per source served as evidence to support our proposition and sub nodes.

\section{$<$ Insert Table 4>}

Evidence for Proposition 1 and sub construct Sport were sourced from four of the five cases (Alpha, Beta, Epsilon, Gamma). For the sub construct $\mathrm{CoO}$ image only two cases provided evidence (Alpha, Epsilon). Information from the case Delta was not identified as a source of evidence for any of these constructs. The total of sources and references is congruent with the results in Table 3 .

In order to show the qualitative coding results of our analysis the most important narratives supporting Proposition 1 are presented and explained in the following section. Further evidence is 
demonstrated in Gamma's communication material, which shows how national athletes influence New Zealand's sport related $\mathrm{CoO}$ and how these athletes help to endorse the national sport identity and New Zealand born brands.

“...there's been lots of good New Zealand triathletes over the last 15 years so we've always had this association with these New Zealand triathletes at the Olympics and world championships" (Alpha)

This narrative shows the association of professional athletes and their success with their home country. In this case triathletes from New Zealand are ambassadors for their country, representing it through their sport at global competitions.

"So basically at the same time the sport of triathlon was becoming more professional, there started to be this international circuit, like a world cup circuit and like there was a race in New Zealand in 1995 and that's where [Alpha] launched and basically this brand just arrived in the triathlon market." (Alpha)

This narrative shows how sport events of a specific and new sport discipline in a country can create associations for this country with that specific sport discipline. In this way countries can achieve the image of being the "home" of a specific sport discipline.

"I think New Zealand, for our particular garments, is a good place for testing, because we do have, probably our hunters are the most rugged in the world, the way we hunt. Rugged, they're tough and burly, and we don't wait, and we don't sit around. We climb up, you know, sheer cliff faces, and a lot of people get killed by doing that." (Beta)

This narrative shows how the manner in which a sport (hunting in this case) is practised can reflect on the country's image. This quote also takes into consideration how the country's environment influences the sport practice which reflects back on the country's image. 
“...New Zealand has nice connotations particularly in the outdoor industry. Outdoor people, people who are into the outdoors tend to be quite worldly, tend to travel a lot. And tend to have a very high opinion of New Zealand..." (Epsilon)

This quote reflects how a country's positive association with the practice of a certain sport can boost its $\mathrm{CoO}$ image even globally through word-of-mouth. As in the previous case, Alpha, this is a selfreinforcing circle. As the reputation of a country for a certain sport practice increases, more people visit the country to practice the sport and again more word-of-mouth communication is generated.

\section{Proposition 2}

Table 5 shows the quantitative coding results for Proposition 2 and its sub constructs.

$<$ Insert Table 5>

Overall 95 references were coded referring to 33 sources (18 excluding double use of sources). One reference is defined as under Proposition 1. The strongest coding was identified for the sub construct Sport category brands (56 references), while for the sub construct Category-country associations least evidence was found (15 references). For Proposition 1, which combines the two sub constructs, 24 references were found.

As in Table 4, Table 6 shows the sources, cases, and references that informed our theorised Proposition 2 and its sub nodes.

$<$ Insert Table 6>

Evidence for Proposition 2 and the sub node Category-country associations was sourced from all five cases (Alpha, Beta, Delta, Epsilon, and Gamma). The sub node Sport category brands was informed by all cases except Delta. The total of sources and references is congruent with the results in Table 5 . 
In order to show the qualitative coding results of our analysis the most important quotes supporting Proposition 2 are presented and explained in the following section. Further evidence is shown in Gamma's communication material that illustrates the use of a $\mathrm{CoO}$ image in marketing and advertising materials in order to position the brand and to leverage the brand value.

\begin{abstract}
"Being a company from New Zealand is crucial for Beta's story and brand. [...] Firstly, the historically grown hunter, fisher and farmer scene is relevant for the credibility of Beta's products and promises that come along with them in terms of performance and durability." (Beta)
\end{abstract}

This narrative shows how $\mathrm{CoO}$ image related to the outdoor category hunting and fishing has helped to create a brand in this outdoor sport segment. Historical development of this outdoor activity assures credibility of the brand.

"Delta also thinks that being from New Zealand is extremely relevant for their success overseas because New Zealand is well known as an outdoor nation. Hence as a nation where good outdoor apparel and equipment is developed and designed." (Delta)

This quote illustrates the importance of New Zealand's reputation for outdoor activities and how this image related to outdoors leverages local firm's ability to market outdoor apparel and equipment.

"My purpose was to create a new category around natural-tech products [...] and we'll always be based in New Zealand, it is very important to us, and we think, a lot of our story is based on the New Zealand story. [...] there's a lot of merino growing around the world, not just in New Zealand. [...].” (Epsilon)

This quote shows how the superior image of a particular resource (in this case, merino wool) of a country that is used for the production of high performance sports apparel has led to a high association of a particular sport product category (merino performance apparel) with a particular country (New Zealand). This has been explored by local firms to develop global brands in the respective sport product category. 


\section{Proposition 3}

Table 7 shows the quantitative coding results for Proposition 3 and its sub constructs.

$<$ Insert Table 7>

Overall 70 references were coded referring to 29 sources (14 excluding double use of sources). One reference is defined as under Proposition 1 and 2. The strongest coding was identified for the construct Proposition 3 (34 references). A similar high score of sources and references was coded for the sub construct Global outdoor brands (31 references), while for the sub construct Outdoor CoO little evidence could be found (5 references).

As in Tables 4 and 6, Table 8 shows the sources, cases, and references that informed our theorised Proposition 3 and its sub nodes.

$<$ Insert Table 8>

Evidence for Proposition 3 was sourced from all five cases (Alpha, Beta, Delta, Epsilon, Gamma) as well as for sub node Global outdoor sport brands. The sub node Outdoor CoO was only informed by the cases Alpha, Beta, and Gamma. The total of sources and references is congruent with the results in Table 7.

In order to show the qualitative coding results of our analysis the most important narratives supporting Proposition 3 are presented and explained. Further evidence reveals Gamma's communication material that illustrates the presentation of an outdoor brand in specialised journals launched on the properties of New Zealand's sport related CoO.

“And so with the merino story we can say, well we've got this heritage of, like, world champion triathletes and the Ironman and all these different materials we use and people are at the Olympics wearing [our] stuff." (Alpha) 
This quote describes that different country-specific factors related to outdoor sport such as domestic professional athletes, hosting of well-known sport events, and the participation at global sport competitions can be used to heighten knowledge and credibility of a specialised outdoor brand.

"Furthermore New Zealand as location is and was important for the international success of the outdoor product range. New Zealand's reputation for outdoors has supported the credibility of Epsilon's products in the outdoor segment." (Epsilon)

This narrative shows how a country's reputation for the outdoors has legitimised the development of a local outdoor brand. The country's $\mathrm{CoO}$ image related to the outdoors increases the credibility and authenticity of the outdoor brand from that country.

\subsubsection{Results for the yachting sector}

The analysis for this sector was conducted as for the outdoor clothing case data and the results of that analysis are now presented.

Table 9 shows the quantitative coding results for Proposition 1, 2, and 3, and its sub constructs.

<Insert Table 9>

Overall 17 references were coded for Proposition 1 and its sub constructs, 25 references for Proposition 2 and its sub constructs, and only 6 references could be identified for Proposition 3 and its sub constructs. The strongest coding was identified for the construct Proposition 2 followed by Proposition 1, while for Proposition 3 little evidence could be found.

References were identified in all cases and in many of the sources to inform our theorised Proposition 3 and its sub nodes. Out of a total of 19 sources, 10 different sources were used. Evidence was sourced from all five cases (Lambda, Omega, Psi, Rho, and Sigma) for Proposition 1 or its sub nodes. 
Proposition 2 or its sub nodes were informed by all cases except Omega. Evidence for Proposition 3 was only found in cases Lambda, Sigma and Rho.

In order to show the qualitative coding results of our analysis the most important narratives supporting Proposition 1 are presented and explained in the following section.

“The clustering thing's becoming more important, I think we're being recognised more and more as a sail designation, so for the sail boats especially. You've only got to look at all the racing crews around the world and you've got New Zealanders in key positions. You've got New Zealanders also in key positions on a lot of super yachts now, driving the super yachts, or engineering, or both, and crewing on board the super yachts." (Lambda)

This quote shows that the success of national athletes in professional racing teams can influence the athlete's home country $\mathrm{CoO}$ regarding the industry related to that sport.

"Also the boat building and marine cluster that had evolved in New Zealand due to its natural endowment with coastline and hence the enthusiasm of people for marine activities was a favourable characteristic of the location New Zealand." (Omega)

This narrative illustrates how activities related to water sport have been influencing the country's $\mathrm{CoO}$ image. This permitted a whole industry to develop on the back of this reputation in marine activities.

The most important narratives supporting Proposition 2 are presented and explained next. Further evidence can be drawn from Rho's communication material as they use the slogan "built with pride in New Zealand" on their logo. This illustrates the use of CoO image of New Zealand in one of our example brands.

"New Zealand is an island nation that is extensively involved in water activities. The marine industry in New Zealand is growing and [Rho] has been recognized as the market leader in 
response to the demand for innovative design, advanced technology and production processes that all aim towards customer satisfaction." (Rho)

This narrative shows how $\mathrm{CoO}$ image related to water sport activities has enabled the creation of a specialized sport category brand that enjoys high reputation and notoriety in its market.

Proposition 3 was so weakly supported with only three references for Proposition 3, 0 references for the sub construct Outdoor $\mathrm{CoO}$ and 6 references for the sub construct Global outdoor brands, that we abandoned it for this case setting.

\subsection{Results for the inductive analysis}

An inductive analysis was carried out on the outdoor clothing sector data investigating the question of how outdoor sport equipment firms develop their brands. The within case results are now presented. Alpha

Alpha started developing its brand in the triathlon segment in close interaction with professional athletes by supplying them with sports apparel at national and international sport events which gave the new brand much public and media exposure: "So we made the suits for the New Zealand triathlon team and then we also sponsored the New Zealand cycling team at the last Olympics. “. The brand name, design, and colours were chosen in association with an predator native to New Zealand that also corresponds with the New Zealand national sport colours: "[...] and the colours match with New Zealand's colours [...]”. In recent product diversification Alpha considered location-specific factors in terms of resources commonly used in outdoor clothing apparel and sourced in New Zealand: "I guess there are a few reasons why we went into merino. One was obviously New Zealand has a really good reputation for merino and all of our merino we use is New Zealand merino." Alpha expresses an intended use of New Zealand sport related $\mathrm{CoO}$ image to promote its products and brand: "And so with the merino story we can say, well we've got this heritage of world champion triathletes and the Ironman and all these different materials we use and people are at the Olympics wearing [Alpha]. And we're from New Zealand 
and we have this New Zealand product [...]" Alpha's priority is functionality and this is reflected in its brand. As a high performance niche brand in a sport that has parts of its origins in New Zealand and is still intensively practiced in the country Alpha has benefited from these aspects in developing the brand.

Beta

Beta has built its brand specialising in outdoor hunting apparel and building on commitment to New Zealand as a design and manufacturing location. The products are primarily functional and sold to customers involved in professional or recreational outdoor activities in the domestic market. Beta has a strong link to its $\mathrm{CoO}$ based on local community attachment but it is able to export this affinity in foreign markets: “We have emails come back every week saying it's fantastic, we 're staying New Zealand. So we try to be [a] point of difference, yes we are expensive and the reason why we're expensive is because we are New Zealand made and we stand by our products.". This connectedness to the $\mathrm{CoO}$ is not only expressed regarding the local community but also the local natural environment. The company summarises this in the slogan "Proudly designed and produced in New Zealand" revealing the importance of $\mathrm{CoO}$ for its business and brand.

Delta

Delta started the business and brand in the wider outdoor industry and has moved into the fashion industry over the years. There was no explicit marketing and branding strategy at the outset: company growth was incremental. However, Delta expresses that the $\mathrm{CoO}$ might have helped in the development of the business and brand: "I think New Zealand does have a good name in the outdoor world, I think we are part of that, definitely. It's definitely a plus and people like it." Furthermore New Zealand as $\mathrm{CoO}$ is reflected in Delta's designs: "I think we have a New Zealand design, I think that some of our design's different. I mean we stand out [...] because our design looks different from everyone else." Delta might not have intentionally used $\mathrm{CoO}$ aspects in its brand development because that function has never been in the centre of the business development. However, as the brand has developed over time outdoor related $\mathrm{CoO}$ aspects have influenced and facilitated the brand's development. 
Epsilon

Epsilon is a design oriented outdoor sport and fashion clothing company specialising in merino products. The business and brand started in the outdoor segment and has diversified into other sectors such as fashion, snow, and running over the years. From inception the brand concept was the core of the company and much time and resources have been spent on its development and refinement. Epsilon's CEO explains: "[Epsilon; was to be about the relationship between people, and between people and nature”. In terms of nature and the idea of "kinship with nature” in the firm's brand concept, the firm's CoO New Zealand has played a crucial role because of its outdoor reputation: "When people think where does the best merino come from, a lot of people typically think of New Zealand. So it has become part of our story, and New Zealand has nice connotations particularly in the outdoor industry. People who are into outdoors tend to be quite wordily, tend to travel a lot and tend to have a very high opinion of New Zealand". Being from an outdoors nation has facilitated the leverage of the firm's brand concept and story to enhance its credibility.

\section{Gamma}

Gamma is an outdoor sport apparel business and brand specialising in merino underwear for the action sport market. The brand concept is based on the extant merino sport apparel category and aims at transferring this category into a younger and different sport segment. The brand relies heavily on its $\mathrm{CoO}$ in provocative marketing communication materials: "Underwear \& first layer for the riders lifestyle. Designed in New Zealand." or "Born and bred in Lake Wanaka, NZ” or “[Gamma's] headquarters is in the town of Lake Wanaka, New Zealand, the Southern Hemisphere's winter destination for the world's snowboarding and freeskiing scenes. You could say we are a test laboratory of sorts, an innovative island nation at the bottom of the world that encounters the extremes of weather and often all in one day. It is here that we test every garment and have gained a loyal following who are now helping to take [Gamma] to the World.". Sport related aspects of Gamma's CoO such as elite athlete loyalty and support as well as local outdoor sport environments have clearly been used since inception to leverage it's brand internationally. 


\section{Discussion and Conclusions}

Our results confirm that $\mathrm{CoO}$ image with sport product category-country associations enables the creation of brands in sport product categories (Proposition 2) across both case settings. Sport as a countryspecific determinant of $\mathrm{CoO}$ image (Proposition 1) was, relative to within case setting findings, more strongly supported in case setting 2 (yachting). Conversely, more supporting evidence was found in case setting 1 (outdoor clothing), relative to within case setting findings, that countries with an outdoor sport related $\mathrm{CoO}$ image facilitate the creation of global outdoor sport brands for firms from that country (Proposition 3). Overall case setting 2 (yachting) provided a lower general level of evidence in support of our propositions than case setting 1 (outdoor clothing).

Proposition 1 was supported with 39 references in case setting 1 and with 17 references in case setting 2 . It should be noted that only 14 direct references ( $25 \%$ of total references) to the proposition could be found while the other references relate to sub constructs. However, the latter should be regarded as weaker evidence as they relate to only one part of the proposition and not necessarily the theorised relationship between the two elements of Sport and $\mathrm{CoO}$ image.

Proposition 2 was strongly supported in case setting 1 with 95 references. With 25 references in case setting 2, Proposition 2 was strongly confirmed in the within case setting but less clearly in the between case setting comparison. However, the level of direct references is higher than for Proposition 2 with 35 references (29\% of total references).

Proposition 3 was strongly supported in case setting 1 (70 references) while only partial evidence was identified in case setting 2 (6 references). However, the highest level of direct supporting evidence was found for Proposition 3 with $49 \%$ of references being assigned directly to the construct and the remainder to sub constructs. Despite weak support for Proposition 3 in the deductive analysis, the inductive analysis revealed evidence that New Zealand's outdoor clothing firms create brands building on New Zealand's country-specific factors such as outdoor environment, natural resources, and sporting success and reputation but in a rather passive than active manner. Insufficient support for Proposition 3 in 
the yachting sector could be partially caused by the fact that the yachting sector is more business-tobusiness oriented and less consumer driven. Hence, the development of global consumer brands, on which we focus in this study, plays a subordinate role.

Generally, it can be confirmed that the sport related aspects of a $\mathrm{CoO}$ can facilitate brand creation and the leverage of brand value in the sporting goods sector. Our contribution to research on brand concepts demonstrates the importance of location and product category, thus adding to understanding which so far has favoured the stakeholder model of brand creation. Furthermore, we extend the brand concept in sport to sporting goods brands while previous research was primarily concerned with the brands of sport teams (Chanavat \& Bodet, 2009; Couvelaere \& Richelieu, 2005; Richelieu \& Desbordes, 2009), branding and sponsorship (Chanavat, et al., 2009; Ferrand \& Pagès, 1996) or branding at sport events (Ferrand \& Pagès, 1996; Parent, et al., 2012). However, we identify country and industry sector as important influencing factors for our research question which should be considered and reassessed in replications or further development of this study.

Even though the need to analyse sport as a determinant of $\mathrm{CoO}$ image was identified nearly a decade ago (Dinnie, 2004b), none of the 51 articles that cite Dinnie (2004b) has addressed this issue. Further keyword research combining sport and $\mathrm{CoO}$ has revealed only one recent article that deliberately combines $\mathrm{CoO}$ with sport (White, 2012), which focuses on the role of sport for $\mathrm{CoO}$ image in tourism. Other articles implicitly combine $\mathrm{CoO}$ aspects with research on host cities of sport events (Brown, 2000; Emery, 2010), sport tourism destinations (Hinch \& Higham, 2001), and cultural issues in sport management (Allen, et al., 2010; Thomas \& Dyall, 1999). We conclude that no research has been conducted investigating the role of sport as a $\mathrm{CoO}$ determinant for the creation of sport product brands.

However, the question of brand creation and development is not a new research issue and has been investigated by many researchers and with different perspectives. A very strong model in contemporary research is the stakeholder model of brand creation (Jones, 2005; McEnally \& De Chernatony, 1999). Our contribution complements that model by taking other aspects such as location and location-specific factors 
into consideration beyond the stakeholders of a firm when analysing the process of brand creation, seeing "brands as vectors of national image" (Anholt, 2002, p. 233).

In highlighting the practical relevance of our findings, $\mathrm{CoO}$ is important not only for start-ups and small- and medium-sized enterprises in sport goods industries (which made up our case settings) but also for established firms that wish to expand their products and their brand reputation beyond national borders or to boost their international brand reputation. We emphasise that the research question we investigated is not uniquely applicable to our research setting but can have implications for other industry sectors in the sport goods industry. Examples of other New Zealand-based specialised sport goods brands are Canterbury for rugby equipment and $O B O$ for hockey goalkeeping equipment (Benson-Rea \& Shepherd, 2010; Dalziel, 2011). These firms have been internationally successful by creating international niche brands built partly on sport related $\mathrm{CoO}$ image such as the national women's hockey team success at the Sydney Olympics and the continuous success of the national rugby team the "All Blacks". Furthermore our research has managerial implications for outdoor sport goods firms and industry sectors in other countries. Brands from countries such as Switzerland (e.g. Mammut), Canada (e.g. Canada Goose), Norway (e.g. Helly Hansen) could leverage the sport and nature related aspects of their $\mathrm{CoO}$ image for brand building purposes for example in the mountaineering and winter sport sector. The Swiss sport watch brand "Swatch" has used $\mathrm{CoO}$ image in marketing communications such as the brand logo for a considerable time, not to mention the "Swiss Army" brand (Anholt, 2002). The sport related aspects of Australia's and the North American West Coast's $\mathrm{CoO}$ images have been exploited by the surfing industry to create global surf gear and wear brands (e.g. Billabong, O’Neill, Quiksilver, Roxy, etc.). The emerging kite surf gear and wear brands (e.g. FOne, Naish, North, Core) could take a similar strategy as this sport is much younger.

This leads us to suggestions for further research. We encourage further research that controls for the variables 'country' and 'industry'. Hence, we propose studies in countries with similar or different location-specific factors compared to our case country New Zealand. Following on from our research question we encourage research in other sport good industries and also in sport services industries. We 
welcome the investigation of the extent to which location-specific factors can be leveraged to create global brands in sport related industries. We see some potentially fruitful areas for research to develop knowledge in the field of sport goods brand development. First we suggest the replication of our study in similar case settings to our setting 1 (outdoor clothing) as this provided stronger evidence than our setting 2 (yachting) but in different countries. However, we suggest using a larger case sample and conducting mixed method research in order to increase validity and reliability of the results. We suggest using case study locations in the outdoor sport hubs in the region between Vancouver (Canada) and Seattle (USA), or in the European Alps (the region around Annecy, France; Lausanne, Switzerland; Munich, Germany) as these places were mentioned as important for the outdoor sport industry by the managers we interviewed. Secondly, we suggest investigating the brand development process of a different outdoor sport sector (other than the two studied ones here) in order to investigate the objectivity of our hypothesis, i.e. whether the use of sport related aspects of $\mathrm{CoO}$ image for brand creation is idiosyncratic to the outdoor clothing sector or generalizable to other sport goods sectors. Thirdly, we suggest an investigation of a non-outdoor sport industry to see whether the hypothesised relationship between $\mathrm{CoO}$ and brand creation is limited to outdoor sports due to the location dependence of the activity or whether other sport related $\mathrm{CoO}$ factors can influence sport goods brand creation.

To conclude, the main weakness of our study lies in the limitations around our sample. While the first case setting provided valuable evidence and insight concerning our research question, the second case setting provided less evidence in terms of quantity and quality. This clearly limits the generalisation of our results across the outdoor sport goods sector which was the reasoning that guided our case setting selection. However, we appreciate that this limitation also acts as a clarification of the results, demonstrating that brand creation can be industry sector-specific and does not always function in the same manner. Furthermore it can be argued that brands are less important in case setting 2 (yachting) as compared with case setting 1 (outdoor clothing) which is a more consumer-oriented industry sector. This limitation should be considered in further research in choosing new empirical fields. The second weakness is that we often found overlapping evidence for our different propositions, which may have blurred the 
distinctions between the three different propositions which are clearly distinguishable from a theoretical point of view. However, as theory is only a model of reality we recommend refining the propositions in further research to avoid this.

\section{Acknowledgements}

We wish to thank our interviewees for their participation in our study and we gratefully acknowledge the financial support of the University of Auckland Business School.

\section{References}

Aaker, D. A. (1996). Building Strong Brands. New York: The Free Press.

Allen, J. T., Drane, D. D., Byon, K. K., \& Mohn, R. S. (2010). Sport as a vehicle for socialization and maintenance of cultural identity: International students attending American universities. Sport Management Review, 13(4), 421-434.

American Marketing Association. (2012). Dictionary. Retrieved 08 July 2012, from http://www.marketingpower.com/_layouts/Dictionary.aspx?dLetter=B

Andreff, W. (2008). Globalization of the sports economy. Rivista di diritto ed Economia dello sport, $I V(3), 13-32$.

Andreff, W. (2009). The sports goods industry. In W. Andreff \& S. Szymanski (Eds.), Handbook on the Economics of Sport (2nd ed., pp. 27-39). Cornwall: Edward Elgar Publishing Limited.

Anholt, S. (2002). Foreword. Journal of Brand Management, 9(4/5), 229-239.

Askegaard, S., \& Ger, G. (1998). Product-country images: towards a contextualized approach. European Advances in Consumer Research, 3(1998), 50-58.

AT Kearney. (2011). The Sports Market - Major trends and challenges in an industry full of passion.

Bandara, W. (2006). Using Nvivo as a research management tool: a case narrative. Paper presented at the Quality and Impact of Qualitative Research. 3rd International QualIT Conference, Brisbane, Australia.

Bauer, H. H., Sauer, N. E., \& Schmitt, P. (2005). Customer-based brand equity in the team sport industry. European Journal of Marketing, 39(5/6), 496-513.

Benson-Rea, M., \& Shepherd, D. (2010). OBO: Global Success in a Niche Niche Business. In I. Hunter \& K. Morris (Eds.), New Zealand Case Series: Innovation and Entrepreneurship,176-187. Auckland: McGraw Hill. 
Bilkey, W. J., \& Nes, E. (1982). Country-of-origin effects on product evaluations. Journal of International Business Studies, 13(1), 89-99.

Bodet, G., \& Chanavat, N. (2010). Building global football brand equity: Lessons from the Chinese market. Asia Pacific Journal of Marketing and Logistic, 22(1), 55-66.

Bohm, D. (1977). Science as Perception-Communication. The Structure of Scientific Theories. Urbana, IL: U of Illinois P.

Brodie, R. J., Benson-Rea, M., \& Lewis, N. (2008). Generic Branding of New Zealand Wine: From Global Allocator to Global Marketing. Paper presented at the Fourth International Conference of the Academy of Wine Business.

Brown, G. (2000). Emerging Issues in Olympic Sponsorship: Implications for Host Cities. Sport Management Review, 3(1), 71-92.

Chanavat, N., \& Bodet, G. (2009). Internationalisation and sport branding strategy: a French perception of the "Big Four" brands. Qualitative Market Research: An International Journal, 12(4), 460-481.

Chanavat, N., Martinent, G., \& Ferrand, A. (2009). Sponsor and sponsees interactions: Effects on consumer's perceptions of brand image, brand attachment and purchasing intention. Journal of Sport Management, 23(5), 644-670.

Chetty, S. (2004). On the crest of a wave: the New Zealand boat-building cluster. Entrepreneurship and Small Business, 1(3/4), 313-329.

Couvelaere, V., \& Richelieu, A. (2005). Brand strategy in professional sports : the case of French soccer teams. European Sport Management Quarterly, 5(1), 23-46.

Dalziel, P. (2011). The Economic and Social Value of Sport and Recreation to New Zealand. Christchurch New Zealand: Lincoln University.

Dichter, E. (1962). The world customer. Harvard Business Review, 40(4), 113-122.

Dinnie, K. (2004a). Country-of-Origin 1965-2004: A Literature Review. Journal of Customer Behaviour, $3,165-213$.

Dinnie, K. (2004b). Place branding: Overview of an emerging literature. Place Branding, 1(1), 106.

Eisenhardt, K. M. (1989). Building Theories from Case Study Research. The Academy of Management Review, 14(4), 532-550.

Emery, P. (2010). Past, present, future major sport event management practice: The practitioner perspective. Sport Management Review, 13(2), 158-170.

Ferrand, A., \& Pagès, M. (1996). Image sponsoring: a methodology to match event and sponsor. Journal of Sport Management, 10(3), 278-291.

Ferrand, A., \& Pagès, M. (1999). Image management in sport organizations: The creation of value. European Journal of Marketing, 33, 387-401. 
Fournier, S. (1998). Consumers and Their Brands: Developing Relationship Theory in Consumer Research. Journal of Consumer Research, 24(4), 343-373.

Freeman, R. E. (1994). The politics of stakeholder theory: Some future directions. Business Ethics Quarterly, 4(4), 409-421.

Fullerton, S., \& Merz, R. (2008). The Four Domains of Sports Marketing: A Conceptual Framework. Sport Marketing Quarterly, 17, 90-108.

Gladden, J. M., \& Funk, D. C. (2002). Developing an Understanding of Brand Associations in Team Sport: Empirical Evidence from Consumers of Professional Sport. Journal of Sport Management, 16(1), 54-81.

Glass, M. R., \& Hayward, D. J. (2001). Innovation and Interdependencies in the New Zealand Custom Boat-Building Industry. International Journal of Urban and Regional Research, 25(3), 571-592.

Heath, D. (2006). Icebreaker: The China Entry Decision. Harvard Business School

Hinch, T. D., \& Higham, J. E. S. (2001). Sport Tourism: a Framework for Research. International Journal of Tourism Research, 3(2001), 45-58.

Ireland, A., Satchcroft, A., Mayson, B., \& Janzarik, M. (2009). New Zealand's Marine Cluster. Harvard: Harvard Business School.

Iverson, J. T. (2010). Kiwi Cuvée: The Next Generation of French Wines. Time, Jan 18. Retrieved from http://www.time.com/time/world/article/0,8599,1954571,00.html

Johansson, J. K., Douglas, S. P., \& Nonaka, I. (1985). Assessing the Impact of Country of Origin on Product Evaluations: A New Methodological Perspective. Journal of Marketing Research (JMR), 22(4), 388-396.

Jones, R. (2005). Finding sources of brand value: Developing a stakeholder model of brand equity. The Journal of Brand Management, 13(1), 10-32.

Keller, K. L. (1993). Conceptualizing, measuring, and managing customer-based brand equity. Journal of Marketing, 57(January 1993), 1-22.

Keller, K. L. (2003). Strategic Brand Management Building, Measuring and Managing Brand Equity. Upper Saddle River, New Jersey: Prentice Hall.

Keller, K. L., \& Lehmann, D. R. (2006). Brands and Branding: Research Findings and Future Priorities. Marketing Science, 25(6), 740-759.

Kotler, P., \& Gertner, D. (2002). Country as brand, products, and beyond: A place marketing and brand management perspective. Journal of Brand Management, 9(4/5), 249.

Kwon, H. H., Kim, H., \& Mondello, M. (2008). Does a Manufacturer Matter in Co-Branding? The Influence on Sport Team Licensed Apparel. Sports Marketing Quarterly, 17(4), 109-119. 
Lefkoff-Hagius, R., \& Mason, C. H. (1993). Characteristic, Beneficial, and Image Attributes in Consumer Judgments of Similarity and Preference. Journal of Consumer Research, 20(1), 100-110.

Lewi, G. (2005). Branding management. La marque de l'idée à l'action. Paris, France: Pearson Education France.

McEnally, M. R., \& De Chernatony, L. (1999). The Evolving Nature of Branding: Consumer and Managerial Considerations. Academy of Marketing Science Review, 2(1999), 1-26.

Mudambi, S. (2002). Branding Importance in Business-to-Business Markets. Industrial Marketing Management, 31(6), p. 31-43.

Mullin, B. J., Hardy, S., \& Sutton, W. A. (2007). Sport Marketing Champaign (Illinois): Human Kinetics.

New Zealand Marine Industry Association. (2012). New Zealand Marine Industry. from http://www.nzmarine.com/home.html

NZ Herald. (2010). French 'Kiwi Cuvee' banned in Australia. New Zealand Herald, Jan 9. Retrieved from http://www.nzherald.co.nz/nz/news/article.cfm?c_id=1\&objectid=10619268

NZTE. (2010). New Zealand boat manufacturing and marine industry. Wellington: New Zealand Trade and Enterprise.

Papadopoulos, N. (2004). Place branding: Evolution, meaning and implications. Place Branding, 1(1), 3649.

Pappu, R., Quester, P. G., \& Cooksey, R. W. (2005). Consumer-based brand equity and country-of-origin relationships. European Journal of Marketing, 40(5/6), 696-717.

Parent, M. M., Eskerund, L., \& Hanstad, D. V. (2012). Brand creation in international recurring sports events. Sport Management Review, 15(2012), p. 145-159.

Parent, M. M., \& Séguin, B. (2008). Toward a model of brand creation for international large-scale sporting events: the impact of leadership, context, and the nature of the event. Journal of Sport Management, 22(5), 526-549.

Pons, F., \& Richelieu, A. (2011). How strong is my sports brand? The case of the Montréal Canadiens Hockey Club. Journal of Sponsorship, 4(4), 353-365.

Richelieu, A., \& Desbordes, M. (2009). Football teams going international: A matter of brand positioning. Journal of Sponsorship, 3(1), 10-22.

Roth, M. S., \& Romeo, J. B. (1992). Matching product category and country image perceptions: A framework for managing country-of-origin effects. Journal of International Business Studies, 23(3), 477-497.

Schooler, R. D. (1965). Product Bias in the Central American Common Market. Journal of Marketing Research (JMR), 2(4), 394-397.

SPARC. (2008). Creating a Healthy State for Outdoor Recreation in New Zealand. Wellington. 
Textiles NZ. (2010). Natural Fibre Export Strategy. Retrieved 10 October 2010, from http://www.textilesnz.org.nz/sitedocs/keyactivities/marketdev.aspx

Tiwari, M. K. (2013). Separation of Brand Equity and Brand Value. Global Business Review, 11(3), 421434.

Thakor, M. V., \& Katsanis, L. P. (1997). A Model of Brand and Country Effects on Quality Dimensions. Journal of International Consumer Marketing, 9(3), 79-100.

Thakor, M. V., \& Kohli, C. S. (1996). Brand origin: conceptualisation and review. Journal of Consumer Marketing, 13(3), 27-42.

Thomas, D. R., \& Dyall, L. (1999). Culture, Ethnicity, and Sport Management: A New Zealand Perspective. Sport Management Review, 2(2), 115-132.

Unsworth, S. (2010). Going Global: Orca. Retrieved 09 November 2010, 2010, from http://www.nzte.govt.nz/features-commentary/Commentary/Pages/Going-Global-Orca.aspx

Vargo, S. L. \& Lusch, R. F. (2004). Evolving to a New Dominant Logic for Marketing, Journal of Marketing, 68(1), 1-17.

Verlegh, P. W. J., \& Steenkamp, J.-B. E. M. (1999). A review and meta-analysis of country-of-origin research. Journal of Economic Psychology, 20(1999), p. 521-546.

White, D. (2012). The Ambassadorial Role of Sports in Heightening Country-of-Origin Image. Paper presented at the European Academy of Management 12th Annual Conference, Rotterdam.

Yin, R. K. (2009). Case Study Research: Design and Methods (4th ed.). Los Angeles, Calif.: Sage. 


\section{Tables}

Table 1: Firm profiles of case setting 1 (outdoor clothing)

\begin{tabular}{llllll} 
Firm & Epsilon & Beta & Alpha & Delta & Gamma \\
\hline Year of inception & 1995 & 1994 & 1992 & 1995 & 2009 \\
Year started exporting & 1998 & 1995 & 1995 & 2007 & 2010 \\
No of employees & 250 & 43 & 18 & 5 & $1-2$ \\
Total sales \$NZ million & & & & &
\end{tabular}

${ }^{\text {a }}$ For confidentiality reasons sales volume is presented in ranges: $0<1,1<5,5<20,20<50,50<100,>100$ (in $\$ N Z$ million). 
Table 2: Firm profiles of case setting 2 (yachting)

\begin{tabular}{|c|c|c|c|c|c|}
\hline Firm & Lambda & Sigma & Rho & Psi & Omega \\
\hline Year of inception & 1985 & 1989 & 1988 & 1956 & 1996 \\
\hline Year started exporting & 1990 & 1991 & 1994 & 1966 & 1996 \\
\hline No of employees & 440 & 350 & 50 & 25 & 1 \\
\hline Total sales \$NZ milliona & $>100$ & $>100$ & $50<100$ & $1<5$ & $0<1$ \\
\hline$\%$ of total sales exported & $100 \%$ & $100 \%$ & $40 \%$ & $60 \%$ & $100 \%$ \\
\hline
\end{tabular}

${ }^{a}$ For confidentiality reasons sales volume is presented in ranges: $0<1,1<5,5<20,20<50,50<100,>100$ (in $\$ N Z$ million). 
Table 3: Quantitative coding results for Proposition 1 and its sub constructs (outdoor clothing)

\begin{tabular}{lll} 
& Sources & References \\
\hline Proposition 1 & 6 & 8 \\
Sport & 8 & 25 \\
CoO image & 4 & 6 \\
\hline Total & $\mathbf{1 8 ( 1 0 )}$ & $\mathbf{3 9}$
\end{tabular}


Table 4: Sources of evidence for Proposition 1 (outdoor clothing)

\begin{tabular}{llcc} 
& Case & Sources & References \\
\hline Proposition 1 & Alpha & 2 & 3 \\
& Beta & 1 & 2 \\
& Gamma & 1 & 1 \\
& Delta & 0 & 0 \\
Total & Epsilon & 2 & 2 \\
\hline Sub node "Sport" & & $\mathbf{6}$ & $\mathbf{8}$ \\
& Alpha & 3 & 13 \\
& Beta & 1 & 1 \\
& Gamma & 3 & 9 \\
Total & Delta & 0 & 0 \\
Sub node "CoO image" & Epsilon & 1 & 2 \\
& & $\mathbf{8}$ & $\mathbf{2 5}$ \\
\hline Tlpha & 2 & 4 \\
& Beta & 0 & 0 \\
& Gamma & 0 & 0 \\
& Delta & 0 & 0 \\
& Epsilon & 2 & 2 \\
& & $\mathbf{4}$ & $\mathbf{3 9}$ \\
\hline Total across all nodes & & $\mathbf{1 8}$ &
\end{tabular}


Table 5: Quantitative coding results for Proposition 2 and its sub constructs (outdoor clothing)

\begin{tabular}{lcc} 
& Sources & References \\
\hline Proposition 2 & 11 & 24 \\
Category-country associations & 7 & 15 \\
Sport category brands & 15 & 56 \\
\hline Total & $\mathbf{3 3 ( 1 8 )}$ & $\mathbf{9 5}$
\end{tabular}


Table 6: Sources of evidence for Proposition 2 (outdoor clothing)

\begin{tabular}{llcc} 
& Case & Sources & References \\
\hline Proposition 2 & Alpha & 3 & 5 \\
& Beta & 1 & 1 \\
& Gamma & 3 & 11 \\
& Delta & 1 & 1 \\
Total & Epsilon & 3 & 6 \\
\hline Sub node "Category-country associations" & Alpha & 2 & 7 \\
& Beta & 2 & 3 \\
& Gamma & 1 & 1 \\
& Delta & 0 & 0 \\
Total & Epsilon & 2 & 4 \\
\hline Sub node "Sport category brands" & & $\mathbf{1 1}$ & $\mathbf{1 5}$ \\
& Alpha & 4 & 18 \\
& Beta & 2 & 5 \\
Total & Gamma & 4 & 19 \\
\hline Total across all nodes & Delta & 1 & 2 \\
& Epsilon & 4 & 12 \\
& & $\mathbf{1 5}$ & $\mathbf{5 6}$ \\
\hline
\end{tabular}


Table 7: Quantitative coding results for Proposition 3 and its sub constructs (outdoor clothing)

\begin{tabular}{lcc} 
& Sources & References \\
\hline Proposition 3 & 11 & 34 \\
Outdoor CoO & 4 & 5 \\
Global outdoor brands & 14 & 31 \\
\hline Total & $\mathbf{2 9 ( 1 4 )}$ & $\mathbf{7 0}$
\end{tabular}


Table 8: Sources of evidences for Proposition 3 (outdoor clothing)

\begin{tabular}{llcc} 
& Case & Sources & References \\
\hline Proposition 3 & Alpha & 3 & 7 \\
& Beta & 2 & 2 \\
& Gamma & 2 & 9 \\
& Delta & 1 & 1 \\
Total & Epsilon & 3 & 15 \\
\hline Sub node "Outdoor CoO" & & $\mathbf{1 1}$ & $\mathbf{3 4}$ \\
& Alpha & 2 & 3 \\
& Beta & 1 & 1 \\
& Gamma & 1 & 1 \\
Total & Delta & 0 & 0 \\
\hline Sub node "Global outdoor sport brands" & Epsilon & 0 & 0 \\
& & $\mathbf{4}$ & $\mathbf{5}$ \\
\hline Total across all nodes & Beta & 4 & 10 \\
& Gamma & 2 & 2 \\
& Delta & 3 & 6 \\
& Epsilon & 4 & 1 \\
& & $\mathbf{1 4}$ & $\mathbf{3 1}$ \\
\hline
\end{tabular}


Table 9: Quantitative coding results for Proposition 1, 2, 3, and its sub constructs (yachting)

\begin{tabular}{lcc} 
& Sources & References \\
\hline Proposition 1 & 5 & 6 \\
Sport & 6 & 9 \\
CoO image & 2 & 2 \\
Total & $\mathbf{1 3}$ & $\mathbf{1 7}$ \\
\hline Proposition 2 & 9 & 11 \\
Category-Country associations & 3 & 4 \\
Sport category brands & 8 & 10 \\
Total & $\mathbf{2 0}$ & $\mathbf{2 5}$ \\
\hline Proposition 3 & 3 & 3 \\
Outdoor CoO & 0 & 0 \\
Global outdoor brands & 3 & 3 \\
\hline Total & $\mathbf{6}$ & $\mathbf{6}$
\end{tabular}

